\title{
PENANGANAN TERHADAP ANAK PELAKU TINDAK PIDANA PENGANIAYAAN YANG TERLIBAT DALAM GENG MOTOR DI WILAYAH BADUNG
}

\author{
Ria Putriliana Waskit, A.A. Sagung Laksmi Dewi, I Made Minggu Widyantara \\ Fakultas Hukum Universitas Warmadewa, Denpasar-Bali, Indonesia \\ jngevens@gmail.com, laksmidewi@gmail.com, Mademingguwidyantara31@gmail.com
}

\begin{abstract}
Abstrak
Geng motor ialah sekelompok pemuda (remaja) yang memiliki kesamaan latar belakang sekolah di daerah yang tergabung dalam suatu komunitas pengguna kendaraan bermotor roda dua. Tindak kejahatan penganiayaan yang dilakukan oleh geng motor anak di Bali telah melanggar ketentuan hukum pidana yang berlaku. Terkait dengan itu, dalam penelitian ini dikaji tentang urgensi modus operandi tindak pidana penganiayaan yang dilakukan oleh anak-anak geng motor dan perlindungan hukum terhadap anak-anak geng motor yang melakukan tindak pidana penganiayaan. Metode yang digunakan dalam penelitian adalah metode Empiris. Modus operandi merupakan modus yang digunakan oleh penjahat untuk melakukan tindakan pidana dan pelaksanaan perlindungan hukum terhadap anak-anak geng motor yang melakukan tindak pidana penganiayaan di wilayah hukum Polres Badung ialah dengan memperhatikan hak anak sebagai terdakwa anak seperti hak mendapat bantuan hukum pada setiap tingkat pemeriksaan menurut tata cara yang ditentukan oleh undang- undang. Sebaiknya, dalam menerapkan sanksi pidana, penegak hukum mempertimbangkan keadaan masyarakat, pelaku kejahatan, demi menumbuhkan kesadaran hukum di dalam diri mereka.
\end{abstract}

Kata Kunci: Perlindungan Hukum; Tindak Pidana Penganiayaan: Geng Motor

\begin{abstract}
A bike gang refers to a group of youths (teenagers) having the same school background in an area who are members of a two-wheeled motor vehicle user community. The criminal act of maltreatment committed by a group of biker gang in Bali has violated the provisions of the applicable criminal law. With regard to the fact, the urgency of the modus operandi of the criminal act of maltreatment committed by biker gang and the legal protection for young biker gang who commit crimes of maltreatment are examined in the present study. The method used in this research is the empirical method. The modus operandi appeared as the mode applied by criminals to commit criminal acts and the implementation of legal protection against bikers who committing the criminal act of maltreatment in the Badung District Police jurisdiction is through not overriding the children's rights as child defendants, such as the right to legal assistance at every level of examination in line with procedures determined by law. It would be better if, in implementing criminal sanctions, law enforcers take the condition of the community, the perpetrators of crimes, into account in order to foster legal awareness within them.
\end{abstract}

Keywords: Legal Protection; Persecution Crime: Biker Gang

\section{PENDAHULUAN}

Masalah tentang nakalnya anak muda kini meresahkan publik. Pada awalnya kenakalan anak muda ini disebut istilah Juvenile Delinquency atau dalam Bahasa Indonesia disebut adalah anak. Pengertian "anak" dianggap terlalu negatif secara psikologis bagi anak sebagai pelakunya; maka dari itu, beberapa ilmuwan menyatakan arti dari Juvenile Delinquency (Sudarsono, 2008: 181). Nakalnya anak muda melibatkan semua perilaku yang berlawanan dari norma dalam masyarakat melanggar status dan melanggar hukum pidana. Penyelewengan status sama dengan kabur dari rumah, tidak hadir di sekolah, merokok, mabuk-mabukan, dan balapan liar. 
Kenakalan anak muda bisa digambarkan sebagai kekandasan dalam memenuhi tugas perkembangan. Beberapa anak muda tidak berhasil dalam mengembangkan dirinya secara positif serta tidak mampu menahan diri seperti yang dilakukan oleh anak lain seusianya selama masa perkembangan mereka (Diananda, 2018). Kesuksesan dalam pemuasan tugas perkembangan menjadikan anak muda sadar dan tanggap terhadap hukum sehingga mereka berupaya menahan dorongan kesenangan dalam diri supaya tidak melanggar hukum dan peraturan berlaku (Choirudin, 2015). Ketidak berhasilnya mereka dalam tugas perkembangan menyebabkan diri anak muda menjadi kurang tanggap terhadap hukum dan peraturan berlaku. Jadi diri pemuda menjadi gampang berperilaku melanggar norma sampai melakukan tindakan kejahatan.

Secara global kenakalan anak dibagi menjadi dua ialah kenakalan sosiologis dan kenakalan individual anak (Nisya \& Sofiah, 2012). Kenakalan anak secara sosiologis terjadi karena seorang anak menentang semua konteks kemasyarakatan hanya khalayak umum. Tujuan dari tindakan itu adalah adalah agar anak tidak merasa bersalah apabila tidak menguntungkan orang lain asal bukan kelompoknya sendiri. Sedangkan, kenakalan anak secara perseorangan terjadi dalam hal anak memusuhi seluruh konteks kemasyarakatan tanpa mengkhususkan, dimulai dari orang tua saudara, tetangga maupun teman sendiri (Diananda, 2018).

Munculnya kenakalan remaja ini bukan semata-mata murni karena keinginan sang anak akan tetapi juga terdapat faktor lain yang mempengaruhi psikisnya sehingga membuatnya melakukan tindakan pelanggaran (Nisya \& Sofiah, 2012). Salah satu penyebab adanya Juvenile Delinquency adalah pengaruh kehidupan keluarga seperti broken home atau quasi broken home (Nisya \& Sofiah, 2012). Selain itu pengaruh lingkungan juga dapat mempengaruhi terciptanya kenakalan remaja namun probabilitasnya lebih rendah.

Beberpa kajian mengenai kenakalan remaja telah diluncurkan, seperti yang dilakukan oleh Tri Raharjo dkk. (2012), Fikri (2012), Jufri (2015), Kurniawati dkk. (2017), dan Wati \& Wirasila (2018). Namun dalam penelitian-penelitian tersebut tidak dikaji tentang modus operandi dalam tindak pidana penganiayaan anggota geng motor, khususnya di wilayah kota Badung, Bali. Berdasarkan hal tersebut, kajian ini menelaah tentang urgensi modus operandi tindak pidana penganiayaan di sebabkan oleh anak geng motor dan perlindungan hukum kepada anak geng motor yang melakukan tindak pidana penganiayaan.

\section{METODE PENELITIAN}

Penelitian ini menggunakan metode penelitian hukum empiris. Metode empiris adalah suatu kegiatan penelitian yang dilakukan secara langsung ke lapangan, yang dalam penelitian ini ialah di lingkungan Polres Badung. Pendekatan yang digunakan adalah pendekatan sosiologis. Sumber bahan hukum yang dipakai pada penelitian adalah bahan hukum primer dan sekunder. Sumber bahan hukum primer ialah informasi yang diberikan oleh informan tentang kasus penindakan kepada anak pelanggar tindak pidana penganiayaan yang terlibat dalam geng motor di Area Polres Badung. Sumber bahan hukum sekunder penelitian ini ialah teori-teori dan hasil-hasil kajian ilmiah yang berkaitan dengan objek penelitian ini yang diperoleh dari buku, artikel jurnal ilmiah dan sumber-sumber lain. Data penelitian ini dianalisis secara kualitatif yang meliputi data dikelompokkan menurut jenisnya dan disesuaikan dengan teori untuk diinterpretasikan menurut kaidah hukum di bidang kenakanlan remaja, khususnya anggota geng motor yang melakukan tindakan penganiayaan. Langkah terakhir ialah menyajikan hasil analisis data dalam bentuk deskripsi dengan bentuk lingual.

\section{HASIL DAN PEMBAHASAN}

\section{Modus Operandi Tindak Pidana Penganiayaan yang Dilakukan oleh Anggota Geng Motor}

Penyelewengan yang dilakukan anak pada umumnya disebabkan oleh kurangnya pemahaman akan hal yang buruk dan baik. Masa remaja ialah masa yang rentan menjalankan tindakan maka masa tersebut merupakan suatu masa dimana anak sangat peka terhadap berbagai harapan demi menggapai sesuatu dan melakukan sesuatu (Dirdjosisworo, 1984: 70). Secara umum modus operandi hadir sebagai sebuah motif yang digunakan penjahat untuk melakukan aksinya. Pada tataran kasus pidana sebelum dilakukan penangkapan dan penyergapan, aparat hukum akan meneliti modus operandi dari penjahat yang diincarnya supaya mempermudah proses penahanan. Modus operandi sifatnya berulang. 
Berdasarkan hasil wawancara pada tanggal 20 Juli 2020 dengan Bapak Ketut Susila, beberapa contoh kasus penganiayaan yang dijalankan oleh anggota geng motor serta modus operandi yang dilakukan adalah sebagai berikut:

I Wayan Rupa menjadi korban penganiayaan serta pengrusakan mobil yang dilakukan oleh sekelompok remaja yang dikira anggota geng motor pada Jumat tanggal 6 Oktober 2017 sekitar pukul 21.30 WITA di Desa Baha. Ada 7 (tujuh) pelaku yang masih di bawah umur. Dua orang menghajar tubuh korban dan lima orang lainnya menjaga agar tidak ada orang yang melihatnya. Peristiwa tersebut berawal ketika I Wayan Rupa tengah berada di perjalanan pulang dari Karang Asem menuju Desa Belayu Kec. Mengwi Kab. Badung. Dari sebelah barat tiba-tiba dirinya berpapasan dengan sepeda motor dari arah berlawanan lalu terdengar kaca mobilnya pecah. Setelah itu korban menepi untuk memeriksa kendaraan dan mendapatkan sebuah batu yang diduga dipakai untuk melempar kaca mobilnya. Melihat korban menepi segerombolan geng motor tersebut mendekati korban dan mulai memukulnya dan menggores serta menusuk bagian tangan dan juga wajah korban hingga memar menggunakan pecahan kaca bekas lemparan dan juga menusuk perut korban hingga membuat korban mengalami kerugian sekitar Rp. 2.500.000,00,- (dua juta lima ratus ribu rupiah). Terkait kasus tersebut, dalam melakukan penganiayaan anggota geng motor menggunakan beberapa modus operandi atau cara untuk menganiaya korbannya. Adapun cara yang digunakan meliputi pelaku menggunakan senjata tajam, yakni pecahan kaca dan pisau yang mengakibatkan korban mengalami luka di bagian perut dan memar di bagian wajah dan tangannya. Itu pun menyebabkan korban tidak bisa melakukan pekerjaannya karena sakit yang dialaminya. Apabila dilihat dalam Kamus Besar Bahasa Indonesia, arti memar itu sendiri merupakan keadaan usang atau hancur di bagian dalam tetapi di luar tidak nampak (Alwi, 2007: 61).

Memar itu disebabkan karena korban jatuh setelah dipukuli. Dia menderita luka tetapi tidak sampai mengakibatkan luka berat. Tindak pidana penganiayaan tersebut memuat unsur-unsur sebagai berikut:

a) unsur kesengajaan: pelaku menggunakan senjata tajam dalam melakukan tindak penganiayaan tersebut adapun senjata tajam yang digunakan pelaku antara lain pecahan kaca dan pisau,

b) unsur perbuatan: p e l a k u menggunakan senjata tajam dalam melakukan aksinya dengan cara memukul dan menusuk korbannya,

c) unsur akibat yang berupa rasa sakit atau luka tubuh. Adanya perbuatan yang mengakibatkan target menanggapi luka di bagian perut dan kerusakan akibat pukulan dan goresan akibat pecahan kaca. Akibat mana menjadi satu-satunya tujuan si pelaku. Rasa sakit atau luka pada tubuh korban menjadi tujuan dari pelaku karena pelaku menyerang korban secara tiba-tiba dengan menggunakan senjata tajam.

Berdasarkan uraian peristiwa tersebut tindak pidana penganiayaan sudah terpenuhi dan pelaku tindak pidana dapat dipidana dengan Pasal 351 ayat (1) KUHP yang menyatakan, "Penindasan diancam dengan pidana penjara paling lama dua tahun delapan bulan atau pidana denda paling banyak empat ribu lima ratus rupiah" Dalam kejahatan dan perbuatan pidana yang dilakoni oleh seorang pasti mempunyai penyebab untuk terjadi, latar belakang kenapa tindakan itu dilakoni.

Beberapa motif atau penyebab anggota geng motor di Bali melakukan tindak pidana penganiayaan. Aksi penganiayaan geng motor yang beranggotakan belasan orang tersebut terjadi saat korban tengah mengendarai sepeda motornya untuk pulang. Korban dicegat dan dihadang dan salah satu pelaku mendekati korban dan mengambil handphone dan sisanya mengawasi bersama-sama. Mereka beraksi bersama-sama di lokasi kegelapan dan menghadang korban dan ada pelaku yang melakukan aksinya dengan memukul korban.

Motif dari terjadinya tindak pidana penganiayaan adalah pengangguran. Pengangguran dapat menyebabkan anak dengan tingkat ekonomi yang rendah melakukan tindak pidana kejahatan karena tidak bekerja sehingga mendorong mereka untuk cenderung frustasi dan dapat berbuat sewenangwenang kepada siapa saja. Terjadinya perselisihan atau konflik yang terjadi antara anggota geng motor anak dan korban merupakan penyebab utama terjadinya tindak pidana penganiayaan ini karena adanya rasa dendam terlebih dulu dan emosi yang tak terkendali yang membuat pelaku melakukan kejahatan.

Prosedur pembentukan karakter anak biasanya dimulai dari perkembangan pada saat anak itu menghabiskan sebagian besar waktunya untuk bergerombol dengan kawannya. Oleh karena itu, 
pengaruh lingkungan pergaulan terlebih lagi pengaruh dari terman bermainnya sangat besar sehingga anak bisa melakoni apa yang dianggap baik menurutnya. Seringkali anak yang berbuat sesuatu yang menyimpang ingin menunjukan jati dirinya kepada masyarakat sekitar agar diakui keberadaannya, ingin dihormati dihargai, dan selalu ingin dipuji serta ditakuti masyarakat sehingga mereka mau melakukan tindakan yang sewenang-wenang kepada siapa saja.

\section{Perlindungan Hukum bagi Anggota Geng Motor yang Melakukan Tindak Pidana Penganiayaan}

Berdasarkan hasil wawancara dengan I Gusti Agung Ayu Mas Asriawati selaku unit PPA di Polres Badung pada tanggal 06 Agustus, upaya penal yang dilakukan oleh Polres Badung sebagai upaya penanggulangan tindak pidana penganiayaan anggota geng motor anak ialah sesuai dengan prosedur yang berlaku untuk kemudian diberikan pemidanaan/hukuman dan pembinaan bagi mereka yang divonis bersalah. Sesuai dengan kewenangannya dalam menangani suatu perkara Polres Badung hanya memiliki peranan memproses perkara dengan melakukan penyelidikan dan penyidikan atas suatu perkara untuk kemudian ditangani lebih lanjut oleh kejaksaan dan pengadilan.

Adapun standar operasional prosedur penanganan kasus hukum oleh Polres Badung yaitu:

\section{Tahap 1 Pelaporan pengaduan}

Pada tahap ini Polres Badung menerima pengaduan maupun laporan dari pihak pelapor yang mengadu dan pelapor harus diperlakukan sama tanpa adanya diskriminasi, intimidasi dan ancaman dari pihak penyidik.

\section{Tahap 2 Penyelidikan}

Penyelidikan dilakukan oleh penyelidik untuk mengejar dan mendapatkan suatu bukti kejadian yang diduga mendapat atau tidaknya dilakukan penyelidikan menurut KUHAP. Penyidikan dilakukan oleh penyidik untuk mengejar dan mengumpulkan bukti untuk membuat jelas tindak pidana yang terjadi dan disengaja untuk mengejar tersangka dari tindak pidana tersebut.

\section{Tahap 3 Penahanan}

Untuk keperluan penyelidikan dan atas perintah, penyidik berkuasa melakukan penahanan

\section{Tahap 4 Penahanan} sesuai bukti permulaan yang cukup.

Berdasarkan bukti yang cukup, penahanan dilakukan untuk kepentingan penyidikan, penuntutan dan pemeriksaan hakim terhadap orang yang diduga kuat melakukan tindak pidana.

\section{Tahap 5 Pengusutan}

Penyidik melakukan pengusutan (pengusutan rumah / badan menurut tata cara yang ditentukan dalam undang-undang untuk kepentingan penyidikan dengan membawa surat

Tahap 6 Penyitaan penggeledahan yang dikeluarkan oleh Pengadilan Negeri).

Pada tahap ini penyidik merebut di bawah penguasaannya.

Restorative Justice merupakan suatu proses di mana segala pihak yang dihubungkan dengan tindak pidana tertentu duduk bersama memecahkan masalah dan memikirkan cara untuk mengatasi akibat pada masa yang akan datang. Prosedur ini dasarnya dilakukan melalui Diskresi dan Diversi yaitu mengalihkan dari proses pengadilan pidana ke luar prosedur formal untuk diselesaikan secara musyawarah. John Restorative justice berfokus pada program keadilan restoratif dalam masalah pidana tetapi perlu dicatat bahwa proses restoratif yang digunakan untuk mengatasi dan menyelesaikan konflik di berbagai konteks dan pengaturan lainnya termasuk sekolah dan tempat kerja (Braithwaite, 2002: 3).

Pelaku pelanggaran pidana oleh pelaku tindak pidana penganiayaan dapat diminta pertanggungjawabannya selaras dengan unsur tindak pidana yaitu sehat jiwanya, menyadari bahwa perbuatannya bertentangan dengan hukum serta mampu mengetahui kehendak sesuai kesadarannya. Dengan demikian ia dapat dipidana oleh Hakim. Arah pemidanaan ini bukanlah suatu penolakan melainkan pembentukan bagi terdakwa yang sudah membuat salah agar dapat mempertanggungjawabkan perbuatannya (Saleh, 1983: 27).

Hal positif dari segi aspek perlindungan anak, asal anak tidak perlu terlalu lama berada dalam bentuk tahanan supaya tidak menghambat pertumbuhan anak secara fisik mental maupun sosial, 
penawanan dilakukan sesudahnya dengan bersungguh dalam mempertimbangkan kepentingan anak atau kepentingan publik. Petugas pemeriksaan anak yang melaksanaan tindakan penawanan harus mempertimbangkan secara matang akibat dari kegiatan penawanan di segala kepentingan anak, seperti pertumbuhan dan perembangan fisik, mental dan social anak. Selain itu kepentingan publik juga perlu dipertimbangkan secara matang; contohnya dengan ditahannya pelaku bisa membuat masyarakat menjadi aman dan tentram.

\section{SIMPULAN DAN SARAN}

\section{Simpulan}

Berdasarkan uraian-uraian di atas, simpulan penelitian ini adalah:

1. Urgensi modus operandi dalam tindak pidana penganiayaan yang dilakukan oleh anggota geng motor anak ialah demi mempersiapkan rencana yang digunakan pelaku menjalankan tindak pidana penganiayaan seketika dengan membawa senjata tajam untuk melukai korban. Pelaku juga nekat melukai korban jika korban melakukan perlawanan. Modus operandi yang dipakai pelaku dalam penganiayaan ini dilakukan dengan terencana baik karena pelaku membawa senjata tajam.

2. Implementasi perlindungan hukum kepada anggota geng motor anak dalam melakukan tindak pidana penganiayaan di wilayah hukum Polres Badung direalisasikan dengan melakukan proses arestasi kepada anak yang diduga melakukan kenakalan berdasarkan bukti yang cukup serta jangka waktu minimal dalam satu hari perlu memperhatikan hak anak sebagai terdakwa anak; termasuk pertimbangan akan hak anak untuk mendapat bantuan hukum di setiap tingkat pemeriksaan sesuai tata cara yang ditentukan oleh undang-undang.

\section{Saran}

Rekomendasi dari penelitian ini ialah sebagai berikut:

1. Pemerintah sebaiknya memperbaiki sistem pengawasan untuk mencegah terjadinya tindakantindakan kejahatan seperti tindak pidana penganiayaan yang sering terjadi yang diperbuat oleh anak di bawah umur serta pemerintah harus menokok anggota kepolisian dan personil aparat hukum lainnya untuk meningkatkan tindakan represif maupun preventif dan untuk lebih meningkatkan penyuluhan hukum kepada anak orang tua dan masyarakat untuk menumbuhkan kesadaran hukum.

2. Aparat hukum dalam menjalankan sanksi pidana kiranya lebih memperkirakan keadaan pelaku yang masih berada di bawah umur mengingat sanksi pidana tidak dapat diterapkan kepada anak.

\section{DAFTAR PUSTAKA}

Alwi, H. (2007). Kamus Besar Bahasa Indonesia. Balai Pustaka.

Braithwaite, J. (2002). Restorative Justice \& Responsive Regulation. Oxford University Press.

Choirudin, M. (2015). Penyesuaian Diri: Sebagai Upaya Mencapai Kesejahteraan Jiwa. Hisbah: Jurnal Bimbingan Konseling Dan Dakwah Islam, 12(1), 1-20.

Diananda, A. (2018). Psikologi Remaja dan Permasalahannya. Journal ISTIGHNA, 1(1), 116-133.

Dirdjosisworo, S. (1984). Sosio Kriminologi Amalan Ilmu-ilmu Sosial dalam Studi Kejahatan. Usaha Nasional.

Fikri. (2012). Sosiologi Penegakan Hukum dalam Kejahatan Geng Motor. Jurnal Hukum Diktum, $10(2), 155-165$.

Jufri, M. (2015). Analisis Kriminologi terhadap Perilaku Geng Motor sebagai Bentuk Kenakalan Remaja di Kota Palu. E-Jurnal Katalogis, 3(12), 76-84.

Kurniawati, H., Purwoto, A. ., \& Astuti, E. S. (2017). Tinjauan Yuridis terhadap Tindak Pidana yang Dilakukan oleh Anggota Geng Motor di Wilayah Polrestabes Semarang. Diponegoro Law Journal, 6(1), 1-12.

Nisya, L. S., \& Sofiah, D. (2012). Religiusitas, Kecerdasan Emosional dan Kenakalan Remaja. Jurnal Psikologi, 7(2), 562-584.

Saleh, R. (1983). Perbuatan Pidana dan Pertanggungjawaban Pidana. Aksara Baru.

Sudarsono. (2008). Kenakalan Remaja: Prevensi, Rehabilitasi dan Resosialisasi. PT. Rineka cipta.

Tri Raharjo, S., Humaedi, S., \& Taftazani, B. M. (2012). Faktor Keluarga dalam Kenakalan Remaja: Studi Deskriptif Mengenai Geng Motor di Kota Bandung. Sosiohumaniora, 14(3), 212-221. 
Wati, E. P., \& Wirasila, A. A. N. (2018). Penanggulangan Tindak Pidana Geng Motor yang Dilakukan Anak di Bawah Umur di Wilayah. Kertha Wicara, 07(02), 1-13. 